\title{
Land mollusks of the California Channel Islands: an overview of diversity, populations, and conservation status
}

\author{
Charles A. Drost ${ }^{1}$,*, Jeffrey C. Nekola ${ }^{2}$, Barry Roth ${ }^{3}$, and Timothy A. Pearce 4 \\ ${ }^{1}$ U.S. Geological Survey, Southwest Biological Science Center, Flagstaff, AZ 86001 \\ ${ }^{2}$ Department of Biology, University of New Mexico, Albuquerque, NM 87131 \\ 3745 Cole Street, San Francisco, CA 94117 \\ ${ }^{4}$ Carnegie Museum of Natural History, Pittsburgh, PA 15213
}

\begin{abstract}
The land snails and slugs have the highest level of endemism among all major animal groups on the California Channel Islands, with nearly $75 \%$ of the native terrestrial species confined to one or more of the 8 islands. In spite of this endemism, and in spite of the rarity of some species, the snails and slugs are one of the most poorly known groups. We present the first comprehensive overview of the land mollusk fauna of the Channel Islands, along with the results of recent intensive inventory studies. Surveys on San Clemente Island have increased the number of land mollusk species known from that island by $50 \%$, and a single survey trip to Santa Rosa Island more than doubled the number of species known on that island. More additions to the land snail and slug fauna are certain for the poorly surveyed northern Channel Islands. This new information has provided insight into trends in species diversity and biogeographic patterns, with marked differences in species composition between the northern and southern islands. Our surveys to date suggest a strong link between the recovery of native vegetation on the islands and the population status of land snails and slugs, with substantially larger numbers of native mollusks on those islands that have been free of nonnative mammals the longest. Survey work is continuing, but it is clear that some very rare endemic snails and slugs on the islands merit specific management attention.
\end{abstract}

RESUMEN.-Los caracoles y las babosas de tierra poseen el mayor nivel de endemismo entre los principales grupos de animales de las Islas del Canal de California (California Channel Islands), donde casi el 75\% de las especies terrestres nativas están confinadas a una o más de las ocho islas. A pesar de ello, y de la rareza de algunas especies, los caracoles y las babosas son, además, uno de los grupos menos conocidos. Presentamos la primera descripción completa de la fauna de moluscos terrestres de las Islas del Canal, junto con los resultados de recientes estudios intensivos de inventarios. Los muestreos en la Isla San Clemente, han aumentado en un $50 \%$ el número de especies de moluscos terrestres conocidos, y un único viaje de muestreo a la Isla Santa Rosa duplicó con creces el número de especies conocidas en esa isla. El crecimiento de la fauna de caracol y babosa terrestres de las Islas del Canal del norte son innegables, a pesar de haber sido escasamente estudiadas. Esta mejora en la comprensión ofrece nuevos conocimientos sobre las tendencias en la diversidad de las especies y los patrones biogeográficos, con marcadas diferencias en cuanto a la composición de las especies, siendo más evidente entre el norte y el sur de las islas. Hasta la fecha, nuestros estudios sugieren un fuerte vínculo entre la recuperación de la vegetación nativa de las islas y el estado de las poblaciones de los caracoles y babosas terrestres, con un número sustancialmente mayor de moluscos nativos en estas islas, las cuales permanecieron libres de mamíferos no nativos durante un tiempo más prolongado. Nuestro estudio continúa, pero está claro que algunas especies de caracoles y babosas endémicas muy raras de las islas merecen especial atención en cuanto a su gestión.

The land mollusk fauna of the California Channel Islands represents an outstanding but largely overlooked component of the biological diversity of this region. Although there have been preliminary studies (e.g., Kanakoff 1950, Roth 1975, Hochberg 1979, Pearce 1990, Roth 1996), knowledge of the land snail fauna on these islands remains especially poor in areas that are critical to protection and management of the natural resources of the islands. Previous compilations of Channel Islands land mollusks (Roth 1975) found that nearly 75\% of the known species are endemic to the islands, found nowhere else in the world.

Human-caused changes to the islands have had severe negative effects on the flora and fauna there. The introduction of grazing animals and their subsequent increase to large

*Corresponding author: charles_drost@usgs.gov 
numbers, the intentional clearing and cultivation of land, the spread of many invasive nonnative plant species, and the introduction of other nonnative animal species have all had detrimental effects on native plants and animals, including land snails. Some species, such as the large cactussnails in the genus Xerarionta, remain widespread, common, and conspicuous. Other species, however, have been reduced to low numbers in restricted ranges.

From a scientific and conservation standpoint, the mollusk fauna of the islands is valuable in the study of regional biogeographyelucidating (1) the past forces that produced current distribution patterns and levels of narrow endemism and (2) the impending changes that may alter species distributions and numbers. Further, because of patterns of endemism, restricted geographic and habitat ranges, and strong dependence on temperature and moisture regimes, snail and slug species are at particular risk from changes in regional climate. Mollusks represent an extreme in terms of their limited ability to migrate to suitable new habitats when their current range becomes unsuitable.

Our objectives here are to provide a current overview of land mollusk species diversity for the California Channel Islands, including new data from recent and ongoing surveys of each of the islands, a preliminary description of biogeographic patterns, and an assessment of the current conservation status of the species. We summarize what is known about the population status and trends of different species on the islands, the occurrence and distribution of nonnative snails and slugs, and what is known of the rarest species on the islands. Our primary focus is on terrestrial mollusks, but we also include data on freshwater and semiaquatic species.

\section{Methods}

\section{Study Area}

This overview covers the 8 California Channel Islands, located off the southern California coast between Point Conception on the north and San Diego on the south. The islands consist of 2 groups-a chain of 4 northern islands and the 4 more widely separated southern islands. They range in size from Santa Cruz Island at $250 \mathrm{~km}^{2}$, in the northern chain, to Santa Barbara Island at $2.6 \mathrm{~km}^{2}$, in the southern group. Distance to the nearest point on the mainland varies from $19 \mathrm{~km}$ for Anacapa Island, at the east end of the northern chain, to $98 \mathrm{~km}$ for San Nicolas Island, in the southern group (Power 1980). The islands are characterized by a Mediterranean climate modified strongly by the surrounding ocean (Power 1980). Precipitation falls primarily during the cool winter, and summer temperatures are typically mild. Vegetation on the islands ranges from xeric cactus-dominated communities to grassland and coastal shrub communities to pine- and oak-dominated forests on the large islands.

\section{Literature and Museum Specimen Review}

We reviewed published literature, unpublished reports, and museum specimen data for the land snails and slugs on the California Channel Islands. Particularly important regional museum collections for the Channel Islands include the Natural History Museum of Los Angeles County, the Santa Barbara Museum of Natural History, the San Diego Natural History Museum, and the California Academy of Sciences. One of us (TAP) is the Curator of Mollusks at the Carnegie Museum of Natural History, and the extensive collections there are also an important source of information for the islands. We gathered data at these museums on species, locations, numbers, and habitat, and we assembled other ecological information where available. Older records at these museums serve as an important historical baseline from which to evaluate trends in snail distribution and numbers.

\section{Field Surveys}

New field surveys on all of the islands are ongoing, adding to years of work by the authors on the southern islands, particularly San Nicolas, Santa Barbara, and San Clemente Islands. Field sampling methods include visual searches (primarily for the larger snail and slug species) and turning of surface cover (rocks, logs, and artificial cover) to find shells and aestivating snails. These searches are conducted during both the active rainy season, and during the dry season throughout the remainder of the year. An important part of our field survey methodology is systematic sampling of leaf litter (e.g., Nekola 2009, 
Nekola and Coles 2010). The majority of land mollusk species, and the great majority of individuals, are $<5 \mathrm{~mm}$ in size and cannot be reliably documented by visual searches (Nekola 2009). We use the protocol developed for sampling conducted across North America for the minute land mollusk taxa (Nekola and Coles 2010). This protocol employs a nested sieve for separating a coarse litter/snail fraction $(>2 \mathrm{~mm})$ and a fine fraction $(0.6-2.0 \mathrm{~mm})$. Typical samples require field sieving of $2-4 \mathrm{~m}^{2}$ of total surface area and result in a total collected sample of about $500 \mathrm{~mL}$ (litter plus snails). Final processing (sorting, identification, and counting) is completed at lab facilities. Consistency in field methodology allows comparisons among different habitats on individual islands, as well as with other island and mainland sites.

Voucher specimens are collected for identification and documentation. They are deposited at the Natural History Museum of Los Angeles County, Santa Barbara Museum of Natural History, Carnegie Museum of Natural History, and other institutions. Most of these specimens are empty shells, though some living/aestivating individuals are collected for internal morphology study (which is sometimes required for identification) and for genetic analyses of specific groups. Known rare species are documented by photographs and empty shells. Scientific and common names reported here follow Roth and Sadeghian (2006) and Turgeon et al. (1998), except as noted.

\section{RESUlTS}

\section{Mollusk Diversity}

There are a total of 49 terrestrial and aquatic or semiaquatic snails and slugs documented from the Channel Islands, and one freshwater clam (Table 1). These represent 22 taxonomic families, with 14 of the families being native (wholly or in part) and 8 of the families being nonnative. The most diverse, and often the most numerous in terms of population numbers, are the Helminthoglyptids, with 13 species (all 13 species are endemic to the Channel Islands; Table 1, Figs. 1, 2), and the tiny Vertiginids, with 5 species (all but one endemic to the islands; Fig. 3). Among the 44 terrestrial snails and slugs, 33 species are native and 11 species are nonnative. The terrestrial mollusk species total includes 8 slugs or semislugs ("semislug" is used here for the endemic slug snail Binneya notabilis, which has a small flat shell in the center of its back), and 5 of these are nonnative. Five aquatic or semiaquatic snail species have been documented from the islands, along with one freshwater bivalve; one or two of these are introduced. Records with a question mark in Table 1 reflect uncertainty of either the validity of the record or the species identification. For the island tightcoil snail on San Clemente Island, a single fragmentary shell that appears to be from a Pristiloma species was found during field surveys on that island in September 2014; the specimen is a member of the family Pristilomatidae and is tentatively assigned to Pristiloma shepardae. In the genus Vertigo on Santa Barbara Island, both V. californica longa and V. catalinaria have been reported by previous authors (Hochberg 1979), but positive identification awaits genetic analyses of specimens. The meadow slug (Deroceras laeve) was reported on San Nicolas Island by Pearce (1993: appendix), but the species has not been found in more recent surveys.

There is one widespread freshwater snail on the Channel Islands: the European physa (Physa acuta) is found on all of the islands with perennial fresh water-even small seeps, as on San Nicolas Island. Despite its common name, this snail is a native, cosmopolitan species that is spread widely by birds (Wethington and Lydeard 2007; see also Ramsden 1914). The big-eared radix (Radix auricularia) was introduced to North America in the late 1800s (Mills et al. 1993) and is now widely distributed across the United States and Canada. The species has a patchy distribution in California, including the southern California mainland in proximity to Santa Catalina Island (Kipp et al. 2017). The record from Santa Catalina Island (Santa Barbara Museum of Natural History \#141949) is the only report from the Channel Islands. The Mexican rams-horn (Planorbella tenuis) may also be introduced to Santa Catalina Island, as records for this species are in or near nonnatural, impounded ponds on the island. The 2 truncatella species (Truncatella californica and T. stimpsonii) occur in beach-cast eelgrass and kelp on low-energy beaches adjacent to sheltered marine waters. They occur on some of the Baja California Islands (Isla San Martín) north to Santa Catalina Island, and along the coast to San Diego. On Santa Catalina Island, 


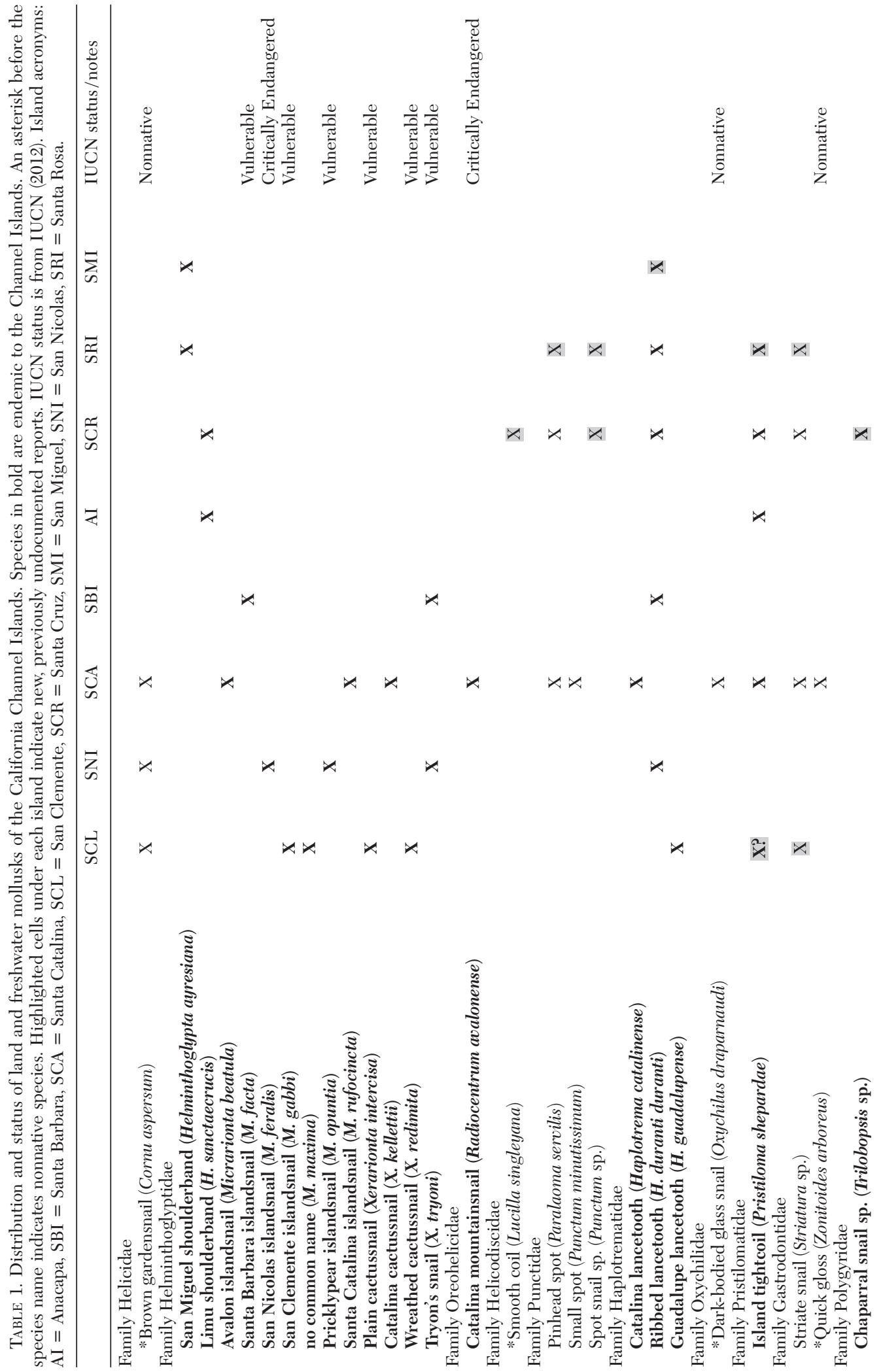


Drost et al. • Channel Islands Land Mollusks

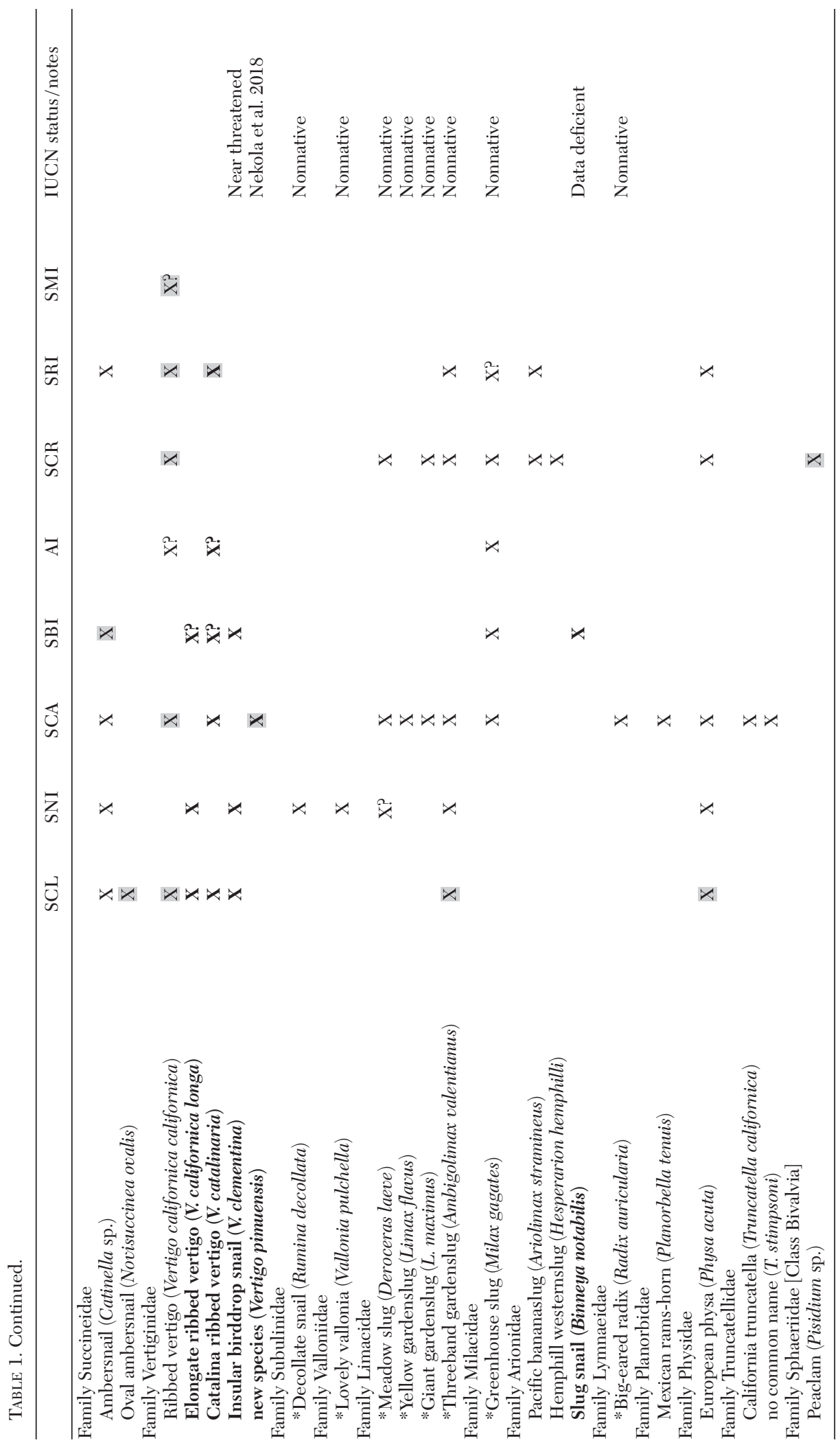




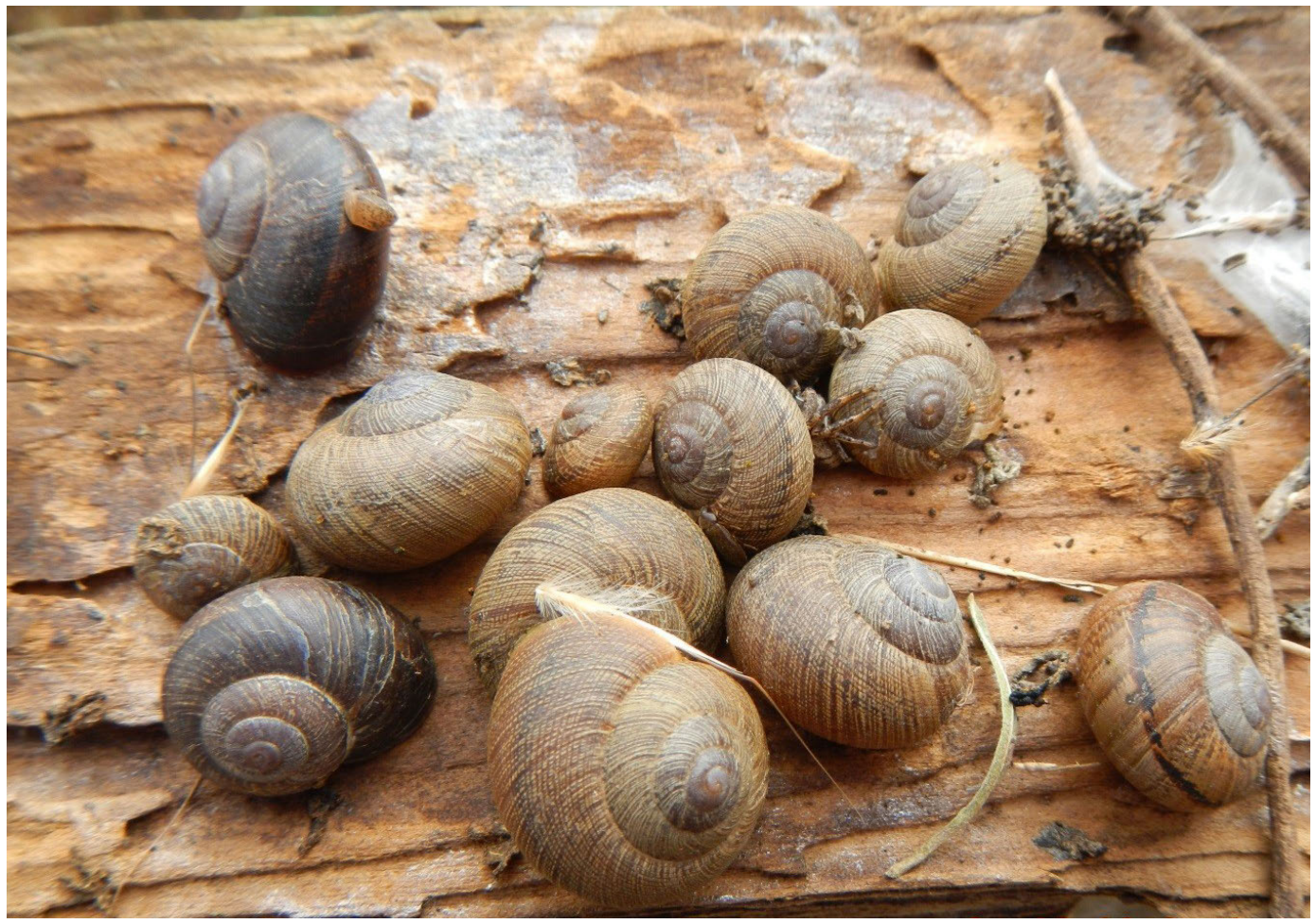

Fig. 1. Aestivating cactussnails on the underside of a board on San Clemente Island. Most are the heavily ribbed plain cactussnail (Xerarionta intercisa); the 2 large, dark individuals at the upper and lower left, and the individual with the prominent dark band at the lower right, are wreathed cactussnails (X. redimita). Four cactussnail species are endemic to the 4 southern Channel Islands. U.S. Geological Survey photo by C.A. Drost.

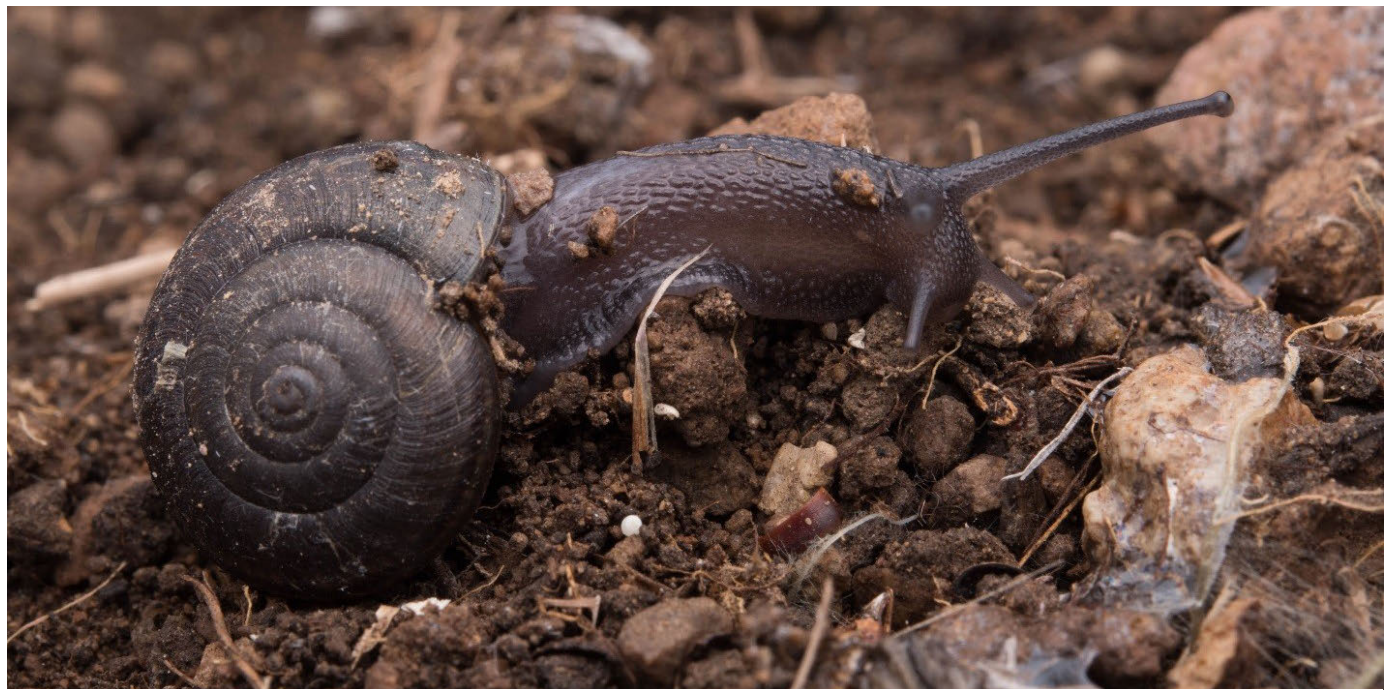

Fig. 2. Active individual of the Limu shoulderband snail (Helminthoglypta sanctaecrucis) on Santa Cruz Island. This is the common large snail on Santa Cruz and Anacapa Islands. The shell of this individual is unusually dark. The closely related San Miguel shoulderband (Helminthoglypta ayresiana) is found on Santa Rosa and San Miguel Islands. Photo courtesy of W. Hoyer, U.S. Navy. 


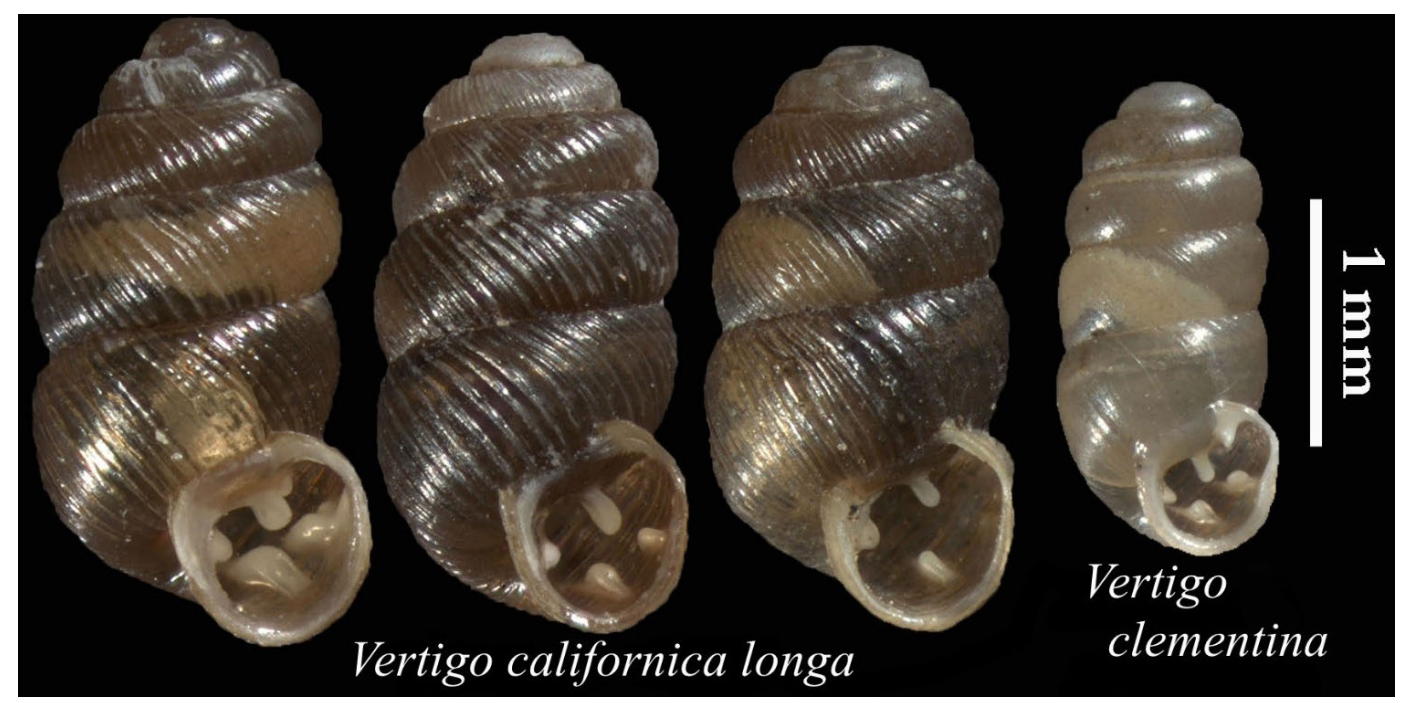

Fig. 3. Two of the smallest snail species in the land mollusk fauna of the California Channel Islands. Though they typically go unseen, in favorable habitat on some of the islands individuals of these species may number in the hundreds or thousands per square meter. Photo by J. Nekola.

TABLE 2. Species numbers of terrestrial snails and slugs, and aquatic and semiaquatic mollusks, on the California Channel Islands. Note that the number of endemic terrestrial species is a subset of the number of native species for each island. Island abbreviations are listed in the caption of Table 1.

\begin{tabular}{lrrrrrrrr}
\hline & SCL & SNI & SCA & SBI & AI & SCR & SRI & SMI \\
\hline Terrestrial & 13 & 7 & 13 & $7-8$ & $3-4$ & 10 & 10 & 3 \\
$\quad$ Native & $8-9$ & 6 & 8 & $6-7$ & $2-3$ & 4 & 4 & 2 \\
$\quad$ Endemic & 2 & $4-5$ & 8 & 1 & 1 & 5 & $1-2$ & 0 \\
$\quad$ Nonnative & 1 & 1 & 5 & 0 & 0 & 2 & 1 & 0 \\
Aquatic & 16 & $12-13$ & 26 & $8-9$ & $4-5$ & 17 & $12-13$ & 3 \\
Total SPECIES & & & & & & & \\
\hline
\end{tabular}

these species have only been reported from the protected beaches at Two Harbors (Pilsbry 1948). Similarly protected, low-energy beaches do not appear to be available on the other Channel Islands.

Our recent field surveys have substantially increased the known land mollusk fauna for some of the islands. Surveys in 2013 and 2014 on San Clemente Island increased the number of species known from that island by $60 \%$, from 10 species prior to 2013 to 16 at present (Table 1; species total includes 2 nonnative species and 1 aquatic species). Similarly, surveys in 2016-2018 increased the known fauna from 11 to 17 on Santa Cruz Island and nearly doubled the species total from 7 to 13 on Santa Rosa Island (including aquatic and nonnative species in both cases). New additions to the island mollusk fauna include some species not previously reported on any of the islands (oval ambersnail, Novisuccinea ovalis, on San Clemente Island) and 2 species new to science: a new species of Vertigo on Santa Catalina Island (V. pimuensis, Nekola et al. 2018) and a new chaparral snail (Trilobopsis sp.) on Santa Cruz Island.

Species richness of native land mollusks on the southern Channel Islands ranges from 7 on San Nicolas Island to 13 on San Clemente and Santa Catalina Islands (Table 2). Ten native species are known from both Santa Cruz and Santa Rosa in the northern islands after recent surveys, but these numbers are preliminary; both islands require more extensive study, and the species totals may increase. Anacapa and San Miguel Islands have received the least study of any of the islands, and the species totals for those islands are certain to increaseperhaps substantially. 


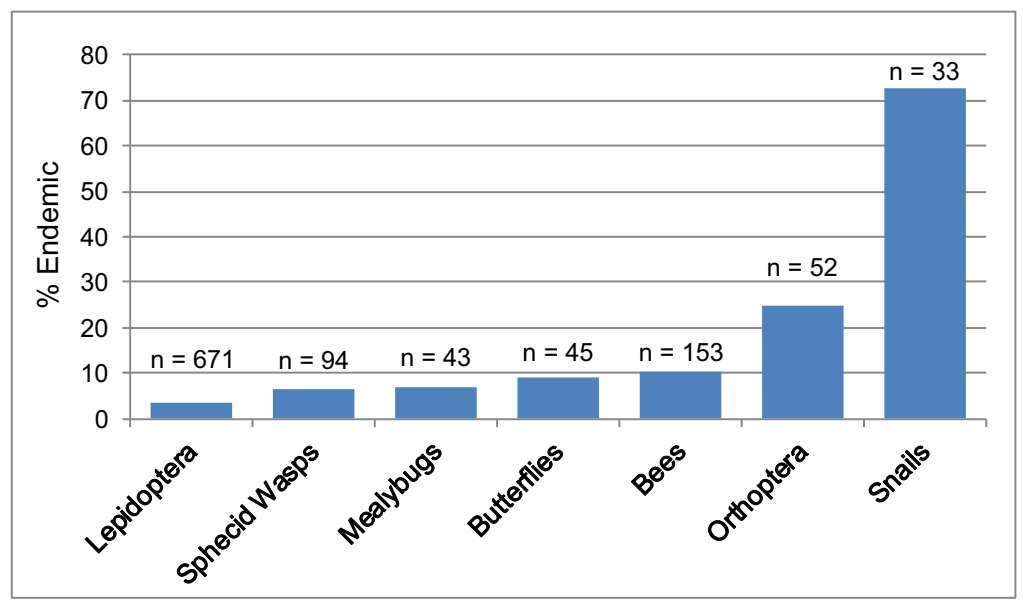

Fig. 4. Comparison of endemism levels among major invertebrate groups of the California Channel Islands. "Lepidoptera" includes all butterflies and moths, and "butterflies" includes only that component of Lepidoptera. References for other invertebrate groups are Rust et al. (1985; mealybugs, bees, and sphecid wasps), Weissman (1985; Orthoptera), and Powell (1985; Lepidoptera, including butterflies). The $n$ above each column indicates the total number of species of that group that are documented on the Channel Islands.

\section{Endemism}

Of the 33 species of native land snails and slugs on the Channel Islands, at least 24 are endemic, or "near-endemic," to the islands (we refer to the Catalina cactussnail, Xerarionta kellettii, as near-endemic; in addition to Santa Catalina Island, it is also known from the adjacent Palos Verdes Peninsula on the mainland). These species represent $73 \%$ of the land snail and slug fauna on the islands. The southern islands have a higher proportion of endemic species compared to the northern islands (Table 2). The level of endemism on the southern islands ranges from 62\% (Santa Catalina and San Clemente Islands) to $86 \%$ (San Nicolas Island) to possibly $88 \%$ on Santa Barbara Island (depending on whether 2 or 3 endemic Vertigo species are present). Based on surveys to date, the 2 best-surveyed northern islands have endemism levels of 40\% (Santa Rosa and Santa Cruz Islands).

The land mollusks have a substantially higher level of endemism on the Channel Islands than other plant and animal groups. The endemism level of land snails and slugs is 3 to over 10 times higher than other invertebrate groups that have been studied, including grasshoppers and crickets (Orthoptera), butterflies and moths (Lepidoptera), and bees and wasps (Hymenoptera; Fig. 4). Endemism levels for vascular plants on the Channel
Islands are generally under $10 \%$, except for on San Clemente Island, where $15 \%$ of the native plant species are endemic (Raven 1967, Oberbauer 2002).

\section{Relative Abundance and Rarity}

Our field surveys record the numbers of snails of each species at each sample site. All of the Channel Islands are recovering from severe impacts of domestic and feral grazing animals and other large mammals, and substantial differences in numbers of snails on the different islands show a clear relationship to the span of time since large nonnative mammals were removed from each island (Table 3). The last large mammals were removed from Santa Cruz and Santa Rosa Islands within the last 10 years, while San Clemente Island has been free of nonnative large mammals for close to 30 years, and San Nicolas Island for nearly 70 years (McChesney and Tershy 1998, Lombardo and Faulkner 2002, Garcelon et al. 2005, Knowlton et al. 2007, Junak 2008, and Parkes et al. 2010). Diversity and particularly abundance of land snails is markedly higher on the latter 2 islands. Species richness was nearly as high at a few sites on Santa Cruz Island and Santa Rosa Island, but consistently high diversity was recorded at sampling sites on San Clemente Island and San Nicolas Island. Large snail 


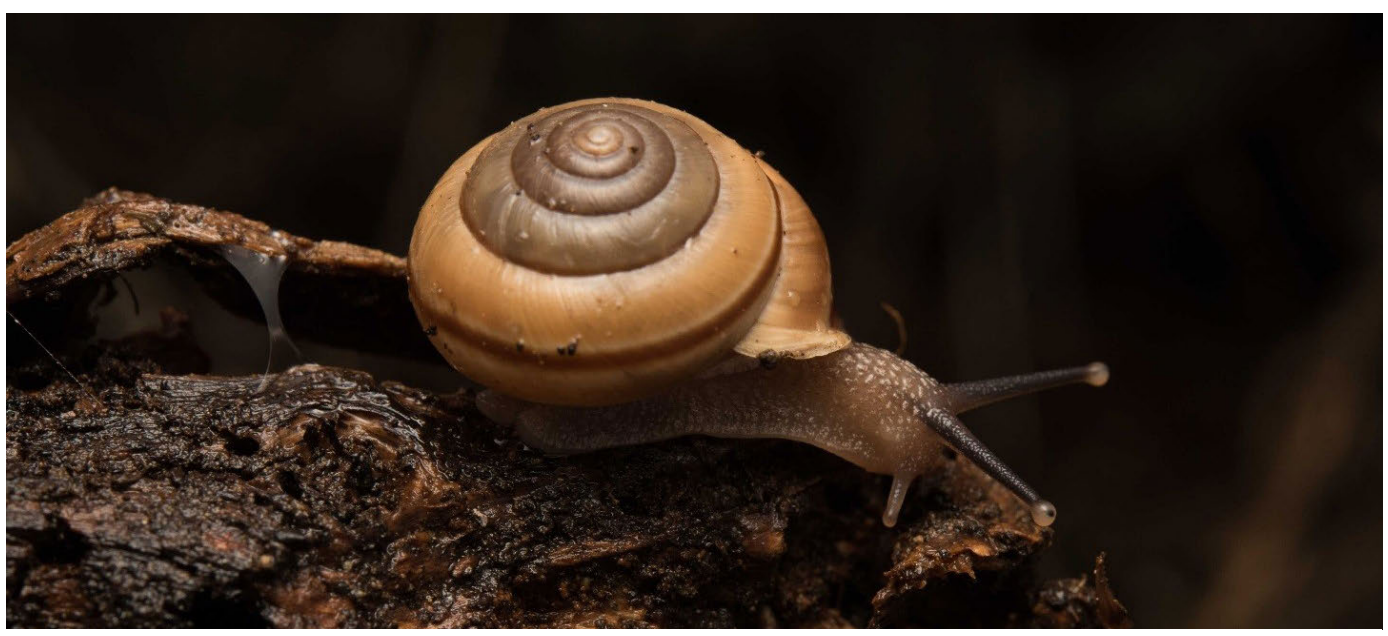

Fig. 5. An active individual of the San Nicolas islandsnail (Micrarionta feralis). This species is known only from an area of about 2 ha on San Nicolas Island. This species, along with the Catalina mountainsnail (Radiocentrum avalonense) on Santa Catalina Island and the slug snail (Binneya notabilis) on Santa Barbara Island, are 3 of the rarest land mollusks on the California Channel Islands. Photo courtesy of W. Hoyer, U.S. Navy.

TABLE 3. Land snail abundance on 4 of the California Channel Islands in relation to removal of nonnative grazing animals. "Date removed" is the approximate year that the last large, nonnative mammals on the island were removed; "snail richness" is the maximum number of snail species per sample site; "mean number" is the average count of large snail species (Helminthoglypta, Micrarionta, Xerarionta). See text for further explanation.

\begin{tabular}{llccr}
\hline Island & Last large mammals & Date removed & Snail richness & Mean number \\
\hline Santa Rosa & Mule deer, elk & 2011 & 5 spp. & 1.0 \\
Santa Cruz & Feral pig & 2007 & 5 spp. & 1.8 \\
San Clemente & Feral goat & 1989 & 7 spp. & 12.9 \\
San Nicolas & Feral sheep & 1949 & 6 spp. & 12.1 \\
\hline
\end{tabular}

species were ubiquitous on San Clemente and San Nicolas Islands (islandsnails, Micrarionta spp., and cactussnails), while large snails (shoulderbands, Helminthoglypta spp.) were absent from most sites on Santa Cruz and Santa Rosa Islands and were present in only low numbers at others. In favorable sites on the southern islands, numbers of large snails could be exceptionally high, with maximum counts of 162 per site on San Clemente Island and 231 on San Nicolas Island. Numbers of the minute snails, like the Vertigo species, followed the same pattern; numbers in single samples ranged into the hundreds and sometimes thousands at sample sites on the southern islands, with high counts of 1524 per sample on San Clemente Island and 3087 per sample on San Nicolas Island. Where Vertigo was found on the northern islands (Santa Cruz and Santa Rosa), numbers were less than 50-100.
None of the Channel Islands species are listed as Threatened, Endangered, or Candidate for Listing under the U.S. Endangered Species Act, nor by the State of California (CDFW 2017), but at least 3 species are known to be highly restricted in distribution and numbers. Two of these-the San Nicolas islandsnail (Micrarionta feralis) on San Nicolas Island (Fig. 5) and the Catalina mountainsnail (Radiocentrum avalonense; see Hochberg et al. 1987) on Santa Catalina Islandare listed as Critically Endangered by the International Union for Conservation of Nature (Table 1). The third-the slug snail on Santa Barbara Island-is listed as "Data deficient." All 3 species are found on single islands and have total known ranges of $<2$ ha. Several other species that are endemic to the Channel Islands are listed as "Vulnerable" or "Near Threatened" (Table 1), but the remaining species lack designated IUCN status. 


\section{Nonnative Species}

One-fourth of the overall total of 44 land snails and slugs on the Channel Islands are nonnative species. Most or all of these nonnatives evidently arrived on landscape and ornamental plants and other materials that were brought to the islands. The highest numbers of nonnative species have been recorded on Santa Catalina Island (8 nonnatives out of 21 terrestrial species, 38\%) and San Nicolas Island (5 out of 12 terrestrial species, $42 \%$; Tables 1, 2). Most of these introduced species are generally restricted to developed areas and other sites with supplemental water. At least 2 nonnatives are known to be spreading, however. The decollate snail (Rumina decollata) was first documented on San Nicolas Island in 1983 in an area of planted, nonnative pine trees in the U.S. Navy town area. This species had spread by about $0.4 \mathrm{~km}$ after 12 years (Tupen and Roth 2001) and has now spread over an area of approximately $1 \mathrm{~km}^{2}$, with some individuals found up to $1.7 \mathrm{~km}$ from the point of introduction. This species is a concern because it is known to prey on other snail species. Also on San Nicolas Island, the brown gardensnail (Cornu aspersum; also called Helix aspersa) was first found in 1980 at sites of ornamental plantings on the northwest part of the island. Gardensnails have now spread over approximately $7 \mathrm{~km}^{2}$ of stable dune and mixed shrub native habitat on the western half of the island.

\section{Discussion}

The 8 California Channel Islands support at least 33 native terrestrial snails and slugs. The 11 nonnative species that have been introduced to one or more of the islands, plus 6 aquatic and semiaquatic mollusks, bring the total documented mollusk fauna to 50 species (Tables 1, 2). Some of the islands clearly need further inventory work, particularly the 4 northern Channel Islands. Single week-long trips to Santa Cruz and Santa Rosa Islands in 2016 increased the known native land mollusk fauna on Santa Cruz by over $40 \%$ (from 7 to 10 species) and more than doubled the native species known on Santa Rosa (from 4 to 10 species). New additions include previously undescribed species on Santa Catalina and Santa Cruz Islands. Anacapa and San Miguel Islands need additional survey work. Use of a systematic technique for sieving leaf litter (Nekola 2009, Nekola and Coles 2010) has been particularly important in documenting additions to the island snail faunas and more accurately quantifying distribution and abundance.

Some reports suggest that the northern group of the Channel Islands (San Miguel, Santa Rosa, Santa Cruz, and Anacapa) have fewer land mollusk species (e.g., Chambers 1998). However, our surveys indicate that the supposed lower species richness of the northern islands reflects (at least in part) more limited inventory effort on those islands. The southern islands have larger numbers of large snail species but are lacking native slugs that are found on the northern islands. We expect further inventory study will increase species numbers on all 4 of the northern islands.

Some groups continue to present taxonomic questions. The lancetooth snails (genus Haplotrema) are at present represented by 3 species on the islands (Table 1). However, across the 5 islands where the ribbed lancetooth (H. duranti duranti) occurs, there is evident variation in shell features that may represent additional specific or subspecific differentiation. Differentiation between the northern and southern island forms seems particularly likely. The ambersnails (Catinella spp.) have long been taxonomically difficult (Pilsbry 1948, Burch 2008); several different names have been applied to specimens from the Channel Islands, and at least some of these are clearly incorrect. One of us (BR) dissected and examined fresh Catinella specimens collected in our surveys, and the reproductive anatomy identified these specimens as belonging to the subgenus Mediappendix. Pending further study, we are listing the ambersnails from both the northern and southern islands as simply Catinella sp.

Sixteen of the 24 Channel Islands-endemic land snail species are restricted to a single island. All of these single-island endemics occur on the southern islands except for the new chaparral snail species on Santa Cruz Island. The islandsnails and cactussnails contribute the majority of these single-island endemics. Further study of local distribution and abundance is needed on some of the islands, but many of the endemic species are widespread and numerous on the islands on which they occur. Three species stand out as 
particularly rare and in need of management consideration: (1) the slug snail on Santa Barbara Island, (2) the San Nicolas islandsnail on San Nicolas Island, and (3) the Catalina mountainsnail on Santa Catalina Island.

Nonnative snails and slugs have come to represent one-quarter of the land mollusk fauna, with Santa Catalina, San Nicolas, and Santa Cruz Islands having the highest numbers of introduced species. The majority of these introductions are largely confined to human-modified habitats, but at least 2 species have expanded into native habitats. Land managers on the islands have adopted stringent procedures to limit further establishment of nonnative plants and animals, but additional introductions continue to be a threat; in 2016, a live brown gardensnail was found in landscaping materials shipped to San Nicolas Island (W. Hoyer, U.S. Navy, personal communication).

A particularly promising finding of our surveys is the apparent response of native land snails to vegetation and soil recovery following removal of disturbance by large nonnative mammals on the islands. Recovery of vegetation, and subsequent recovery of native snail and slug populations, may take place on a timescale of decades-though it may be possible to accelerate recovery through active management efforts. Vegetation restoration programs on the islands and control of nonnative mammals where they still occur will also benefit the unique native land mollusks of the Channel Islands.

\section{ACKNOWLEDGMENTS}

We thank Lindsey Groves (Natural History Museum of Los Angeles County), Paul Valentich-Scott and Daniel Geiger (Santa Barbara Museum of Natural History), and Casey Richart and Jim Berrian (San Diego Natural History Museum) for assistance with museum specimens and data. Thanks also to Melissa Booker (U.S. Navy, San Clemente Island), Bill Hoyer, Martin Ruane, and Grace Smith (U.S. Navy, San Nicolas Island), Paula Power (Channel Islands National Park), John Knapp (The Nature Conservancy, Santa Cruz Island), and Ben Coleman (Catalina Island Conservancy) who have provided invaluable logistical support for working on the islands. Brian Coles, Terry Arundel, Lisa Gelczis, Kirsten Ironside, and Eric Kortenhoeven assisted with field data collection. Any use of trade, product, or firm names in this publication is for descriptive purposes only and does not imply endorsement by the United States government.

\section{Literature Cited}

Burch, J.B. 2008. Succineidae. Pages 55-57 in K.E. Perez and J.R. Cordeiro, editors, A guide for terrestrial gastropod identification. American Malacological Society, Carbondale, IL.

[CDFW] California Department of Fish and WILDLIFE. 2017. State \& federally listed endangered \& threatened animals of California: January 2017. State of California, Natural Resources Agency, Department of Fish and Wildlife, Biogeographic Data Branch, California Natural Diversity Database; [accessed January 2017]. https://nrm.dfg.ca.gov/File Handler.ashx?DocumentID $=109405$ \&inline

Chambers, S.M. 1998. Channel Islands and California desert snail fauna. Page 618 in M.J. Mac, P.A. Opler, C.E. Puckett Haecker, and P.D. Doran, editors, Status and trends of the nation's biological resources. Volume 2. U.S. Department of the Interior, U.S. Geological Survey.

Garcelon, D.K., K.P. Ryan, and P.T. Schuyler. 2005. Application of techniques for feral pig eradication on Santa Catalina Island, California. Pages 331-340 in D.K. Garcelon and C.A. Schwemm, editors, Proceedings of the Sixth California Islands Symposium. National Park Service Technical Publication CHIS05-01. Institute for Wildlife Studies, Arcata, CA.

Hochberg, F.G. 1979. Invertebrate zoology: land molluscs. Chapter 6 in D.M. Power, editor, Natural resources study of the Channel Islands National Monument, California. Santa Barbara Museum of Natural History, Santa Barbara, CA.

Hochberg, F.G., Jr., B. Roth, and W.B. Miller. 1987. Rediscovery of Radiocentrum avalonense (Hemphill in Pilsbry, 1905) (Gastropoda: Pulmonata). Bulletin of the Southern California Academy of Sciences 86:1-12.

[IUCN] International UNion FOR CONSERvation OF NATURE. 2012. IUCN Red List Categories and Criteria: Version 3.1. 2nd edition. International Union for Conservation of Nature, Gland, Switzerland, and Cambridge, United Kingdom. iv + 32 pp.

JunAK, S. 2008. A flora of San Nicolas Island. Santa Barbara Botanic Garden, Santa Barbara, CA.

KanaKofF, G.P. 1950. Contributions from the Los Angeles County Museum-Channel Islands Biological Survey, No. 34. Some observations on the land snails of San Clemente Island. Bulletin of the Southern California Academy of Sciences 49:79-89.

Kipp, R.M., A.J. Benson, J. Larson, and A. Fusaro. 2017. Radix auricularia. USGS Nonindigenous Aquatic Species Database, Gainesville, FL; (revision 26 June 2014). https://nas.er.usgs.gov/queries/factsheet.aspx? SpeciesID $=1012$

Knowlton, J.L., C.J. Donlan, G.W. Roemer, A. SamaniegoHerrera, B.S. Keitt, B. Wood, A. Aguirre-Muñoz, K.R. Faulkner, and B.R. Tershy. 2007. Eradication of non-native mammals and the status of insular mammals on the California Channel Islands, USA, 
and Pacific Baja California Peninsula Islands, Mexico. Southwestern Naturalist 52:528-540.

Lombardo, C.A., AND K.R. FaulKner. 2002. Eradication of feral pigs (Sus scrofa) from Santa Rosa Island, Channel Islands National Park, California. Pages 300-306 in K.L. Mitchell, D.R. Browne, and H.W. Chaney, editors, Proceedings of the Fifth California Islands Symposium. Santa Barbara Museum of Natural History, Santa Barbara, CA

McChesney, G.J., And B.R. Tershy. 1998. History and status of introduced mammals and impacts to breeding seabirds on the California Channel and northwestern Baja California Islands. Colonial Waterbirds $21: 335-347$.

Mills, E.L., J.H. Leach, J.T. Carlton, and C.L. Secor. 1993. Exotic species in the Great Lakes: a history of biotic crises and anthropogenic introductions. Journal of Great Lakes Research 19:1-54.

NeKola, J.C. 2009. Tiny jewels: an introduction to pupillid taxonomy, ecology, and collection. American Conchologist 37:22-27.

Nekola, J.C., S. Chiba, B.F. Coles, C.A. Drost, T. von Proschwitz, AND M. Horsák. 2018. A phylogenetic overview of the genus Vertigo O.F. Müller, 1773 (Gastropoda: Pulmonata: Pupillidae: Vertigininae). Malacologia 62:21-161.

Nekola, J.C., AND B.F. Coles. 2010. Pupillid land snails of eastern North America. American Malacological Bulletin 28:29-57.

Oberbauer, T. 2002. Analysis of vascular plant species diversity of the Pacific Coast islands of Alta and Baja California. Pages 201-211 in D. Browne, K. Mitchell, and H. Chaney, editors, Proceedings of the Fifth California Islands Symposium. Santa Barbara Museum of Natural History, Santa Barbara, CA.

Parkes, J.P., D.S.L. Ramsey, N. Macdonald, K. Walker, S. McKnight, B.S. Cohen, and S.A. Morrison. 2010. Rapid eradication of feral pigs (Sus scrofa) from Santa Cruz Island, California. Biological Conservation 143:634-641.

Pearce, T.A. 1990. Phylogenetic relationships of Micrarionta (Gastropoda: Pulmonata) and distinctiveness of the species on San Nicolas Island, California. Malacological Review 23:1-37.

Pearce, T.A. 1993. Micrarionta (Gastropoda: Pulmonata) on San Nicolas Island, California. Evolutionary relationship among the species. Malacological Review 26:15-50.

Pilsbry, H.A. 1948. Land Mollusca of North America north of Mexico vol. II part 2. Academy of Natural Sciences, Philadelphia, PA. xlvi + 591-1113.

PoweLl, J.A. 1985. Faunal affinities of the Channel Islands Lepidoptera: a preliminary overview. Pages 69-94 in A.S. Menke and D.R. Miller, editors, Entomology of the California Channel Islands. Santa Barbara Museum of Natural History, Santa Barbara, CA.
Power, D.M. 1980. Introduction. Pages 1-4 in D.M. Power, editor, The California islands: proceedings of a multidisciplinary symposium. Santa Barbara Museum of Natural History, Santa Barbara, CA.

Ramsden, C.T. 1914. The Bobolink (Dolichonyx oryzivorus) as a conveyer of Mollusca. Auk 31:250.

Raven, P. 1967. The floristics of the California islands. Pages 57-67 in R. Philbrick, editor, Proceedings of the Symposium on the Biology of the California Islands. Santa Barbara Botanic Garden, Santa Barbara, CA.

Rотн, B. 1975. Preliminary analysis of the land mollusk faunas of the islands of southern California and northern Baja California [abstract]. Bulletin of the American Malacological Union, Inc. 1975:62.

Roth, B. 1996. The fossil land snail Micrarionta (Micrarionta) intermedia Pilsbry (Gastropoda: Pulmonata): insular phylogeny revisited. Veliger 39:204-212.

Roth, B., and P.S. Sadeghian. 2006. Checklist of the land snails and slugs of California. Santa Barbara Museum of Natural History Contributions in Science No. 3.

Rust, R.W., A.S. Menke, And D.R. Miller. 1985. A biogeographic comparison of the bees, sphecid wasps, and mealybugs of the California Channel Islands (Hymenoptera, Homoptera). Pages 29-59 in A.S. Menke and D.R. Miller, editors, Entomology of the California Channel Islands. Santa Barbara Museum of Natural History, Santa Barbara, CA.

Tupen, J., And B. Roth. 2001. Further spread of the introduced decollate snail, Rumina decollata (Gastropoda: Pulmonata: Subulinidae), in California, USA. Veliger 44:400-403.

Turgeon, D.D., J.F. Quinn Jr., A.E. Bogan, E.V. Coan, F.G. Hochberg, W.G. Lyons, P.M. Mikkelsen, R.J. Neves, C.F.E. Roper, G. RosenberG, et al. 1998. Common and scientific names of aquatic invertebrates from the United States and Canada: mollusks. 2nd edition. American Fisheries Society Special Publication 26.

Weissman, D.B. 1985. Zoogeography of the Channel Islands Orthoptera. Pages 61-68 in A.S. Menke and D.R. Miller, editors, Entomology of the California Channel Islands. Santa Barbara Museum of Natural History, Santa Barbara, CA.

Wethington, A.R., and C. Lydeard. 2007. A molecular phylogeny of Physidae (Gastropoda: Basommatophora) based on mitochondrial DNA sequences. Journal of Molluscan Studies 73:241-257.

Received 2 March 2017

Revised 10 October 2017 Accepted 2 May 2018

Published online 14 December 2018 